\title{
Sternoclavicular hyperostosis
}

\author{
Michael T Flannery, Kara F Villarreal AA
}

\section{CASE REPORT}

Our patient was a 48-year-old white female with a several month history of a non-enlarging, mildly tender $3 \times 3 \mathrm{~cm}$ mass of the medial clavicle and sternum (Figure 1 ). She had a history of moderately controlled hypertension and poorly controlled hypertriglyceridemia. Medications included: lisinopril $20 \mathrm{mg}$, hydrochlorothiazide $12.5 \mathrm{mg}$ and fenofibrate $145 \mathrm{mg}$ daily. Tramadol $50 \mathrm{mg}$ every eight hours was used for pain as needed. There was no history of trauma, erythema, fever, skin lesions or any other bone pain. Physical examination confirmed a solid mass with minimal tenderness and no lymphadenopathy of cervical, axillary or inguinal regions. A magnetic resonance imaging study demonstrated no signs of infection or tumor but there was ossification of the sternocostoclavicular ligaments with loss of the inferior margin of the clavicle. Laboratory studies were normal including complete blood counts, complete metabolic profile, serum and urine protein electrophoresis, quantitative immunoglobulins and an erythrocyte sedimentation rate. Based on the classic findings on exam, with negative laboratory studies, classic imaging without infection or tumor the diagnosis of sternoclavicular hyperostosis was suggested. Followup to date has demonstrated no changes in size or symptoms.

Michael T Flannery ${ }^{1}$, Kara F Villarreal $\mathrm{AA}^{2}$

Affiliations: ${ }^{1} \mathrm{MD}, \mathrm{FACP}$, Professor of Medicine, 12901 Bruce

B Downs Blvd. MDC Box 19 Room L1041, Tampa, Fl;

${ }^{2}$ Pasco-Hernando Community College of Nursing.

Corresponding Author: Michael T Flannery, Professor of Medicine, 12901 Bruce B Downs Blvd.MDC Box 19 Room L1041, Tampa, FI 33612; Ph: 813-974-6443, Fax: 813-9059794; Email: mflann5555@aol.com

Received: 01 March 2014

Accepted: 22 March 2014

Published: 01 June 2014

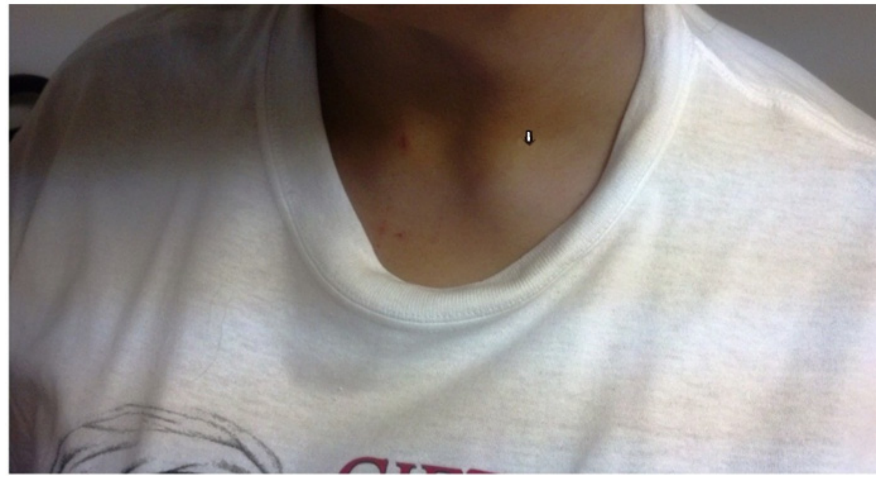

Figure 1: Evidence of bony overgrowth of the sternoclavicular joint on the left (See Arrow).

\section{DISCUSSION}

Sternoclavicular hyperostosis is described as bony overgrowth with soft tissue ossification of the medial clavicle, upper ribs, and sternum [1]. It occurs in both sexes with a broad age range from 11 to 88 years. In a review of 251 cases 139 were Japanese and 114 Caucasian [2]. The most common symptom is pain and while the etiology is unknown, $\mathrm{SH}$ usually starts with nonspecific inflammation of the sternoclavicular ligaments which may lead to chronic inflammation with progressive hyperostosis and soft tissue ossification. The differential includes osteitis condensans, aseptic necrosis, Tietze's syndrome, osteoarthritis, spontaneous subluxation, osteomyelitis and tumors such as osteosarcoma, metastatic breast and prostate cancer, thyroid cancer or extension from a Pancoast tumor of the lung. Biopsy is planned if further enlargement occurs. Approximately $50 \%$ of patients with $\mathrm{SH}$ have skin lesions such as palmoplantar pustulosis, pustular psoriasis, hidradenitis suppurativa and psoriasis vulgaris [3]. Patient's may be treated with non-steroidal anti-inflammatory drugs (NSAID's) for relief if needed. Progression can be monitored over time for increased size or symptoms that may justify biopsy or repeat imaging. 


\section{CONCLUSION}

Sternoclavicular hyperostosis Sternoclavicular hyperostosis is a relatively rarely described process in literature. It is important to recognize this process as a low likelihood of cancer and infection given the patient's presentation, therefore, avoiding an extensive work-up. However, if further growth occurs over time then a biopsy via a fine needle aspiration of the lesion may be warranted along with additional imaging.

\section{How to cite this article}

Flannery MT, Kara F Villarreal AA. Sternoclavicular hyperostosis. Int J Case Rep Images 2014;5(6):459461.

doi:10.5348/ijcri-201458-CL-10046
3. Carroll MB. Sternocostoclavicular Hyperostosis: A Review. Ther Adv Musculoskelet Dis 2011;3(2):10110.

\section{Author Contributions}

Michael T Flannery - Substantial contributions to conception and design, Acquisition of data, Analysis and interpretation of data, Drafting the article, Revising it critically for important intellectual content, Final approval of the version to be published

Kara F Villarreal AA - Analysis and interpretation of data, Drafting the article, Revising it critically for important intellectual content, Final approval of the version to be published

\section{Guarantor}

The corresponding author is the guarantor of submission.

\section{Conflict of Interest}

Authors declare no conflict of interest.

\section{Copyright}

(C) 2014 Michael T Flannery et al. This article is distributed under the terms of Creative Commons Attribution License which permits unrestricted use, distribution and reproduction in any medium provided the original author(s) and original publisher are properly credited. Please see the copyright policy on the journal website for more information.

\section{REFERENCES}

1. Hiramuro-Shoji F, Wirth MA, Rockwood CA Jr. Atraumatic Conditions of the Sternoclavicular Joint. J Shoulder Elbow Surg 2003;12(1):79-88.

2. Petrov D, Marchalik D, Lipsky A, Milgraum S. Asymptomatic enlargement of the clavicle: A Review of underlying aetiologies. Acta Orthop Belg 2010;76(6):715-8. 


\section{ABOUT THE AUTHORS}

Article citation: Flannery MT, Kara F Villarreal AA. Sternoclavicular hyperostosis. Int J Case Rep Images 2014;5(6):459-461.

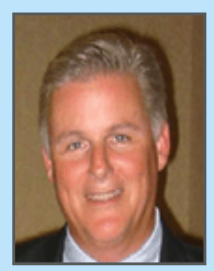

Michael T Flannery is Professor of Medicine at the University of South Florida Morsani College of Medicine in Tampa, Florida. He earned his undergraduate degree in Chemistry from the University of South Florida and postgraduate degree of Medical Doctor from the University of South Florida College of Medicine in Tampa, Florida. He has published approximately 50 academic papers in national and international journals. His main research interest is academic medical teaching in Internal Medicine. His research interests span the spectrum of medical care in Internal Medicine. He plans on continued medical education fo medical students and residents in the future.

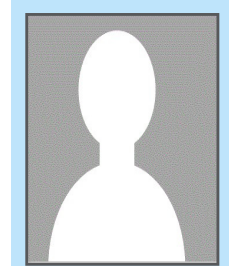

Kara F Villarreal AA is nursing student at Pasco-Hernando State College and will continue her graduate work in Nursing (RN) at the University of South Florida Morsani College of Nursing. She earned her associate's degree in pre-nursing from the Pasco-Hernando State College. This is her first research paper in a national or international academic journal. Her research interests include academic nursing in patient care and infectious disease. She intends to pursue her Master's in Nursing at the University of South Florida Morsani College of Nursing.

Access full text article on other devices

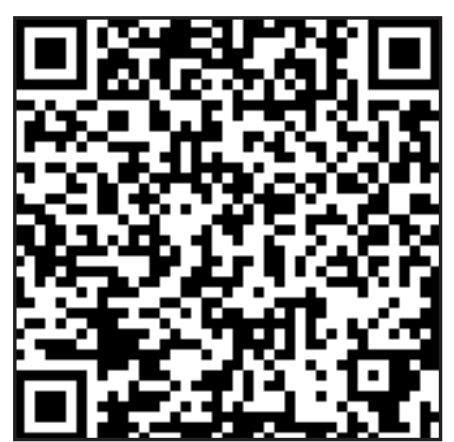

Access PDF of article on other devices

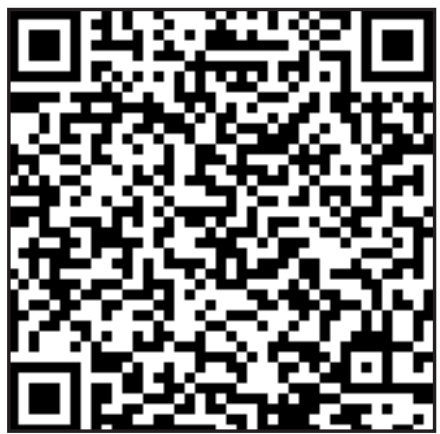

